\title{
Perbaikan Atap Toilet, Pasang dan Plester Dinding, Pasang Keramik dan Pintu Mushola Al Hidayah, Pondok Manggis Rt 03/04, Bogor
}

\author{
Tri Widya Swastika ${ }^{1}$, Sarito $^{2}$, Darul Nurjanah ${ }^{3}$ \\ ${ }^{123}$ Jurusan Teknik Sipil, Politeknik Negeri Jakarta \\ tri.widyaswastika@sipil.pnj.ac.id
}

\begin{abstract}
Abstrak
Berdasarkan hasil wawancara dan pengamatan tim Pengabdian Kepada Masyarakat, ditemukan beberapa permasalahan yang sangat krudensial mengenai keberadaan Mushola Al Hidayah Kampung Pondok Manggis yang sudah tidak layak digunakan sebagai prasarana beribadah umat muslim di lingkungan RT.03/RW.04, Desa Bojong Baru, Kecamatan Bojong Gede, Kabupaten Bogor. Diantaranya yaitu belum terlaksananya pengecoran atap, pemasangan dinding pembatas, plesteran dinding dan pemasangan keramik dinding serta lantai tempat wudhu. Untuk itu perlu dilakukan perbaikan Mushola Al Hidayah, terutama perbaikan pada atap toilet, plester dinding toilet, mengganti pintu toilet, pemasangan keramik dinding dan lantai tempat wudhu, serta pemasangan dan plester dinding penyekat. Dalam mencapai tujuan diatas maka tim Pengabdian Kepada Masyarakat Program Studi Konstruksi Gedung, Jurusan Teknik Sipil, Politeknik Negeri Jakarta, bekerjasama dengan warga secara bergotong royong melakukan perbaikan Mushola tersebut yang dilaksanakan pada tanggal 6 dan 13 Oktober 2018. Dimana target khusus dari kegiatan ini adalah menyempurnakan kondisi fisik Mushola Al Hidayah Kampung Pondok Manggis, RT.03/RW.04, Desa Bojong Baru, Kecamatan Bojong Gede, Kabupaten Bogor. Dengan selesainya pekerjaan tersebut maka tersedia prasarana Mushola yang memadai guna meningkatkan ketakwaan serta keimanan kepada Tuhan Yang Maha Esa.
\end{abstract}

Kata kunci-pengabdian, masyarakat, perbaikan, Mushola, dinding, plester

Abstract
The existence of the Al Hidayah Mosque in Pondok Manggis Village was found to be inappropriate for use as an infrastructure for Muslim worship in the RT.03 / RW.04 neighborhood of Bojong Baru Village, Bojong Gede District, Bogor Regency. For this reason, it is necessary to repair the Al Hidayah Mosque, especially repairs to the toilet roof, plaster of the toilet wall, replace the toilet door, installation of the walls and floors of the ablution place, and the installation and plaster of the insulating walls. In achieving the above objectives, the Community Service Team of the Building Construction Study Program, Civil Engineering Department, Jakarta State Polytechnic, in collaboration with the residents worked together to repair the mosque, was held on 6 and 13 October 2018. Where the specific target of this activity was to perfect the physical condition of the Al Hidayah Mosque in Pondok Manggis Village, RT.03 / RW.04, Bojong Baru Village, Bojong Gede District, Bogor Regency With the completion of the work, there will be an adequate mosque infrastructure to increase piety and faith in God Almighty.

Keywords-community service, repair, prayer room, walls, plaster

\section{PENDAHULUAN}

Dosen sebagai anggota Sivitas Akademika baik secara perorangan maupun kelompok bertugas mentransformasikan Ilmu Pengetahuan dan/atau Teknologi yang dikuasainya kepada Mahasiswa dan memiliki tugas mengembangkan suatu cabang Ilmu Pengetahuan dan/atau Teknologi melalui penalaran dan penelitian ilmiah serta menyebarluaskannya untuk memajukan kesejahteraan masyarakat dan mencerdaskan kehidupan bangsa [1]. Contoh nyata dalam memanfaatkan Ilmu Pengetahuan dan Teknologi adalah dengan kegiatan Pengabdian Kepada Masyarakat.

Kampung Pondok Manggis RT 03/04, Desa Bojong Baru, Kecamatan Bojong Gede, Kabupaten
Bogor merupakakan salah satu wilayah yang terletak disebelah Selatan Kota Depok. Tingkat pendidikan yang lulus SD mencapai 50\%, SMP 30\%, SMA 10\%. Sebagian besar penduduk di Kampung Pondok Manggis bekerja sebagai wirausaha, peternak dan petani. Disamping itu ada juga yang berprofesi sebagai pekerja konstruksi, dan sebagian kecil sebagai karyawan pabrik serta pekerja 'srabutan'. Desa ini berjarak kurang lebih $25 \mathrm{~km}$ dari kampus Politeknik Negeri Jakarta. Letaknya tidak terlalu jauh dari jalan raya Tegar Beriman.

Tim Pengabdian Kepada Masyarakat Program Studi Konstruksi Gedung telah melakukan survei di desa Kampung Pondok Manggis RT 03/04, Desa Bojong Baru, Kecamatan Bojong Gede, bahwa di Desa ini terindikasi adanya tingkat sosial ekonomi 
yang rendah. Hal ini terlihat dari rendahnya tingkat pendidikan, pendapatan, standar hidup dan kesehatan, serta terbatasnya sarana dan prasarana. Desa Bojong Baru, Kecamatan Bojong Gede khususnya Kampung Pondok Manggis RT. 03/04 berpenduduk lebih kurang $70 \mathrm{KK}$, dimana sekitar $50 \%$ dari jumlah KK tersebut hanya berpendidikan sekolah dasar saja. Dengan kondisi masyarakat yang berpenghasilan rendah seperti yang disebutkan di atas, maka sangatlah sulit untuk mengajak masyarakat berpartisipasi membangun desanya khususnya membangun fasilitas yang digunakan bersama, jika ditinjau dari segi pendanaan (keuangan). Hal ini tentunya sangat berbeda jika partisipasi mereka tidak dalam bentuk uang, yaitu berupa sumbangan tenaga (gotong royong). Dari hasil survei juga ditemukan bahwa kondisi Kampung ini mempunyai prasarana ibadah berupa Mushola Al Hidayah namun kondisinyan memprihatinkan sudah banyak bagian-bagian yang mengalami kerusakan serta belum sempurnanya bagian-bagian tertentu yang sebenarnya sangat dibutuhkan . Masyarakat setempat telah berupaya memperbaiki dan menyempurnakannya namun tingkat sosial ekonomi yang rendah menyebabkan perbaikan dan penyempurnaan Mushola tersebut belum bisa direalisasikan.

Sebagai wujud kepekaan sosial terhadap masyarakat terutama bagi masyarakat yang berada di sekitar kampus Politeknik Negeri Jakarta, maka kegiatan pengabdian pada tahun 2018 ini akan dilaksanakan pada perbaikan Mushola Al Hidayah RT 03/04, Kampung Pondok Manggis, Desa Bojong Baru, Kecamatan Bojong Gede, kabupaten Bogor kerjasama dengan Program Studi Teknik Konstruksi Gedung.

\section{METODE PENGABDIAN}

Kegiatan Pengabdian Kepada Masyarakat Kampung Pondok Manggis, Desa Bojong Baru, dilakukan dengan tahapan sebagai berikut:

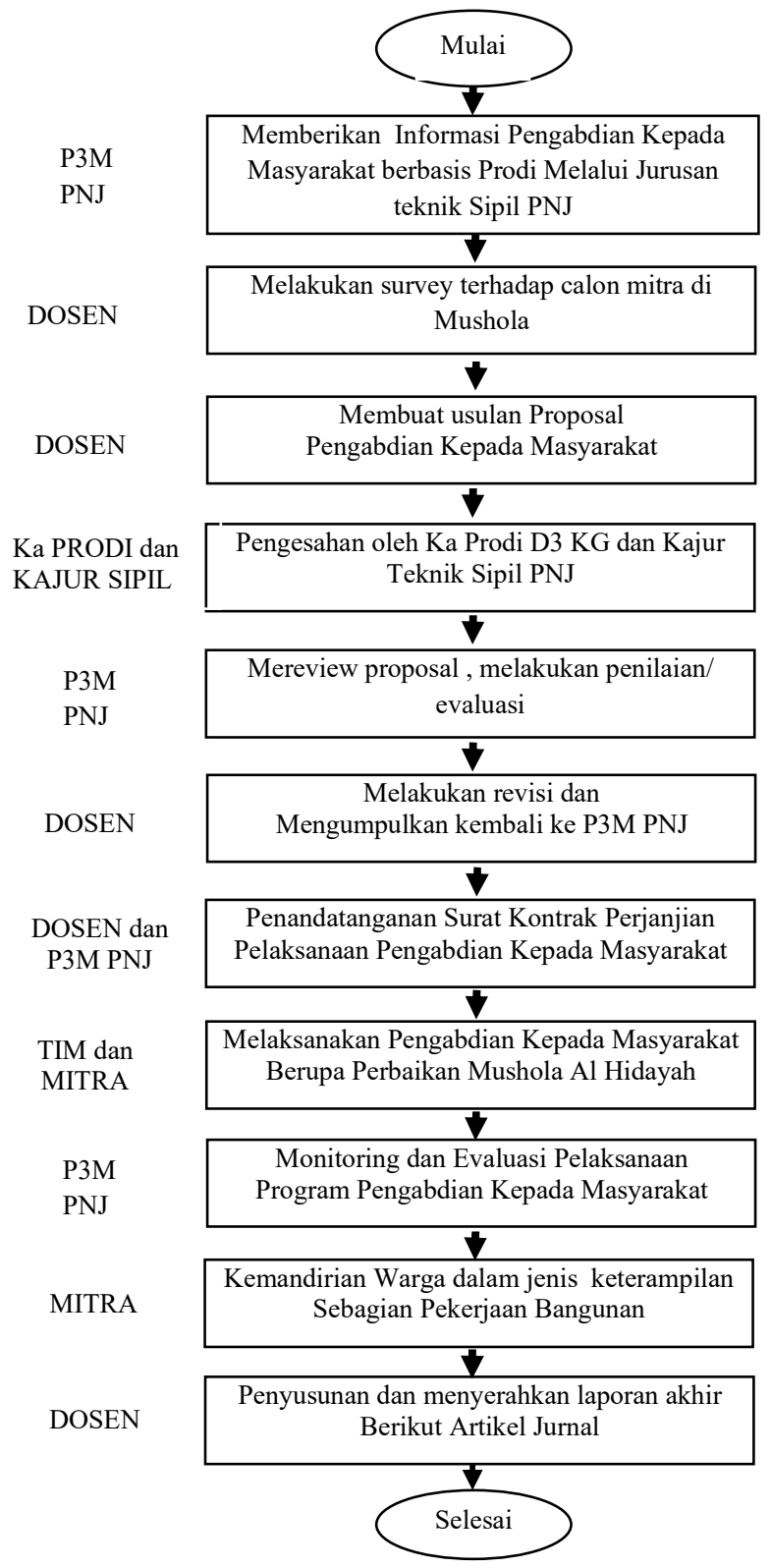

Gambar 1. Tahapan Pelaksanaan Kegiatan

\section{HASIL DAN PEMBAHASAN}

Kegiatan perbaikan Mushola ini melibatkan masyarakat setempat, Dosen serta mahasiswa Jurusan Teknik Sipil PNJ. Personil panitia secara rutin dari proses persiapan hingga pelaksanaan berperan aktif demi terlaksananya kegiatan dimaksud. Masyarakat setempat secara rutin atau pada hari tertentu bergotong royong melaksanakan kegiatan ini dalam kendali panitia dari Prodi Konstruksi Gedung Jurusan Teknik Sipil PNJ. Pelaksanaan kegiatan secara simultan melibatkan Dosen, Mahasiswa dan masyarakat 
setempat dilaksanakan pada hari sabtu tanggal 6 dan 13 Oktober 2018.

Jenis-jenis kegiatan yang dilaksanakan sebagai berikut:

1. Perbaikan Atap Toilet

Atap yang semula rangka dari kayu sudah lapuk dan penutup atap dari asbes sudah pada pecah dan bocor diganti dengan atap cor beton bertulang wiremesh dan bekisting menggunakan floordeck (bondex) didukung dengan kolom dan balok beton bertulang.

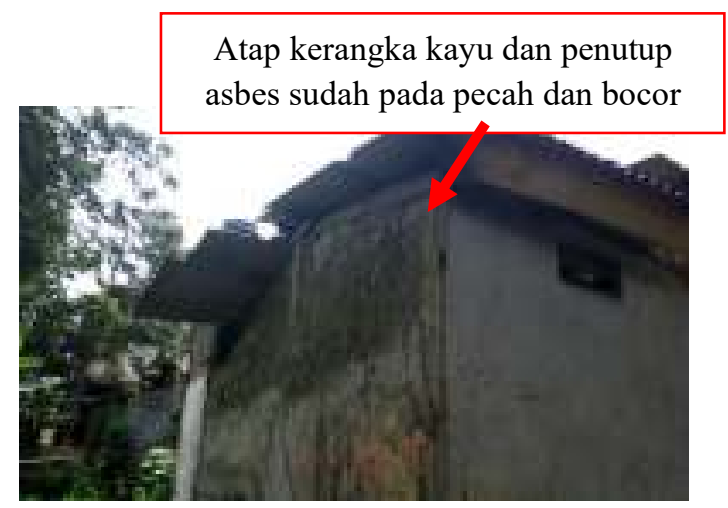

Gambar 2. Kondisi atap eksisting

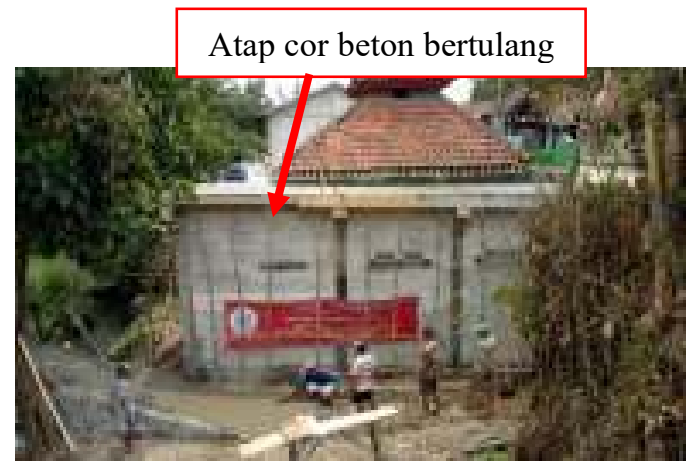

Gambar 3. Atap cor beton bertukang

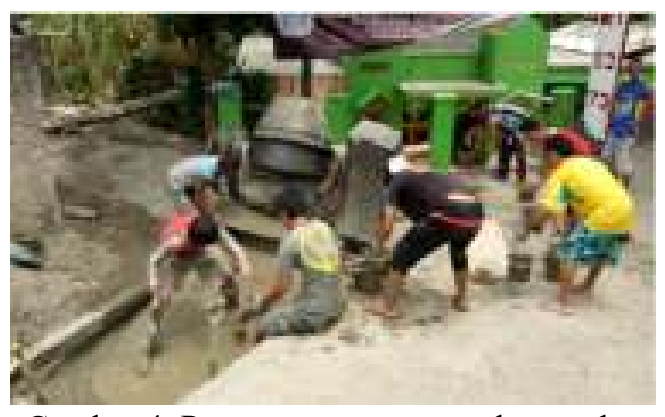

Gambar 4. Pengecoran menggunakan molen

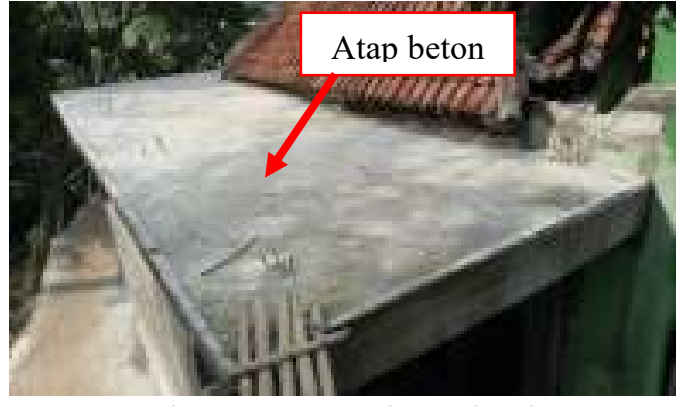

Gambar 5. Atap cor beton bertlang

Pekerjaan perbaikan atap berupa beton bertulang wiremesh dan bondex sampai akhir bulan November 2018 sudah selesai.

2. Pasang Dinding Bata ringan

Pemasangan dinding hebel mengalami perubahan karena kertika proses pemasangan kolom beton bertulang pada atap toilet pada dinding toilet roboh akibat tanpa adanya pondasi, sehingga volume pekerjaan pasang dinding bertambah.

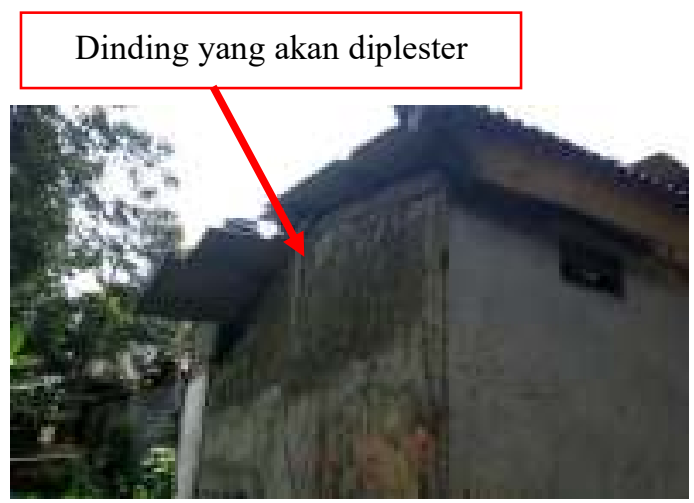

Gambar 6. Dinding eksisting yang roboh

Dinding bagian belakang toilet dan tempat wudhu

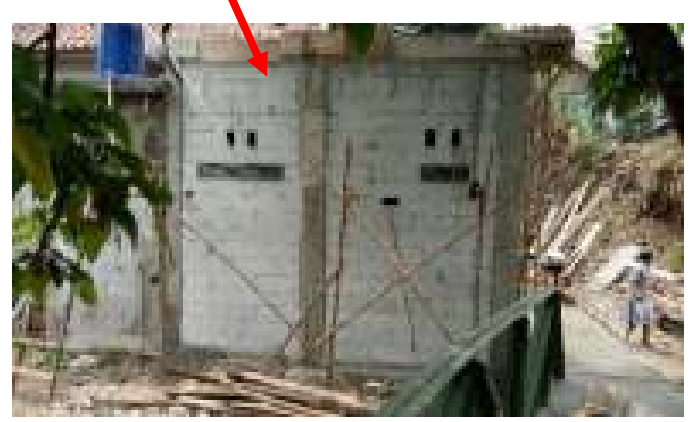

Gambar 7. Pemasangan dinding baru sisi belakang

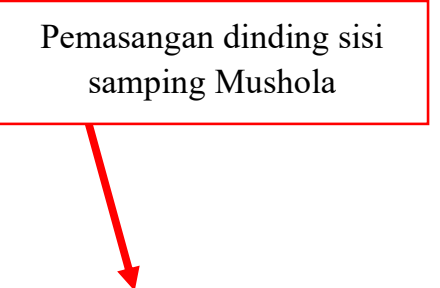




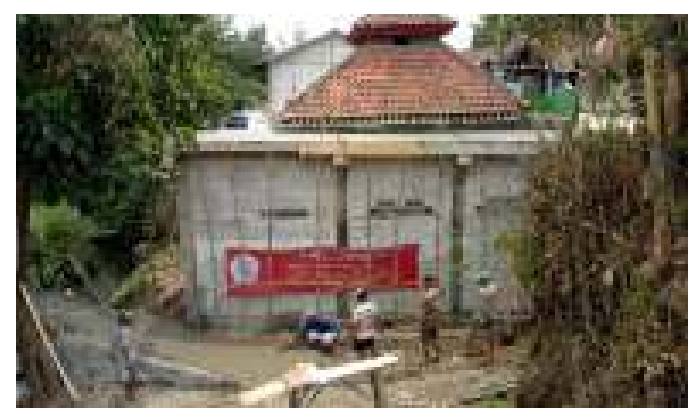

Gambar 8. Pemasangan dinding baru sisi samping

Pemasangan dinding sisi samping dan sisi belakang sampai akhir bulan November 2018 sudah selesai

\section{Plesteran Dinding}

Plesteran luar dan dalam dinding meliputig dinding sisi samping dan sisi belakang Mushola. Pada permukaan sisi samping luar dan dalam serta sisi belakang luar dan dalan sampai dengan akhir bulan November 2018 sudah slesai sampai pada acian. Untuk pekerjaan pengecatan diserahkan swadaya masyarakat setempat.

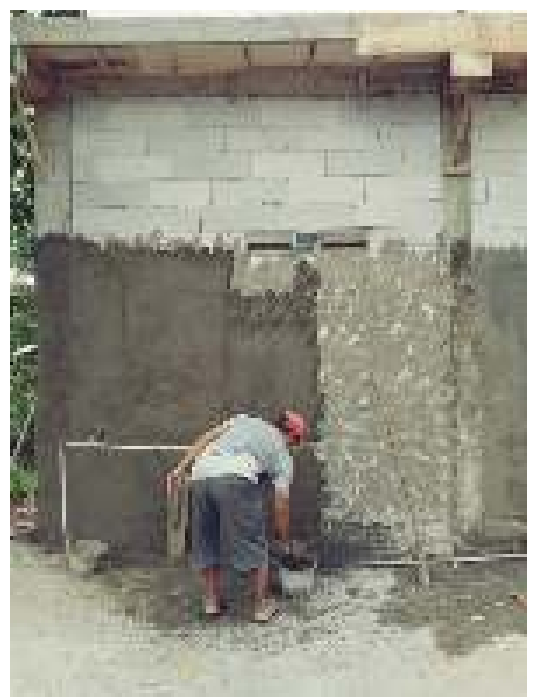

Gambar 9. Pelaksanaan plesteran dinding

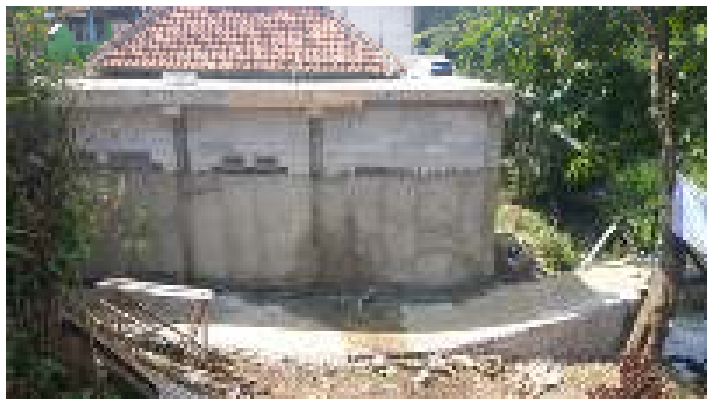

Gambar 10. Plesteran dinding sisi samping

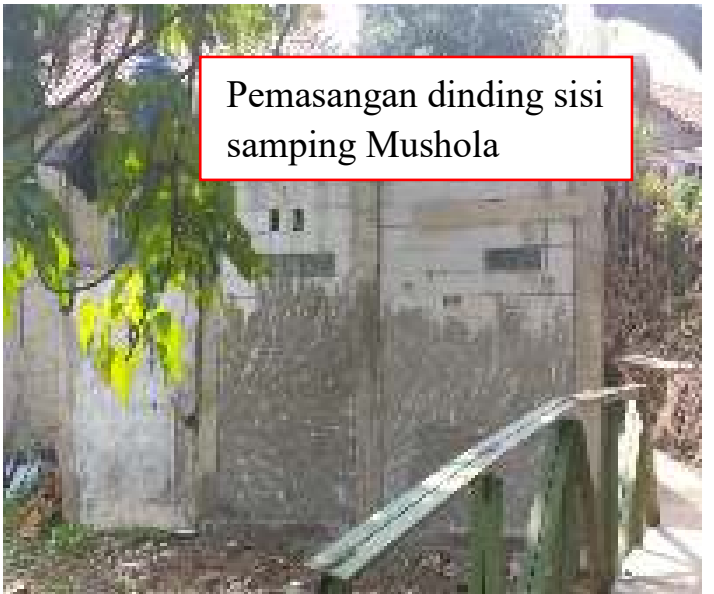

Gambar 11. Plesteran permukaan luar sisi samping

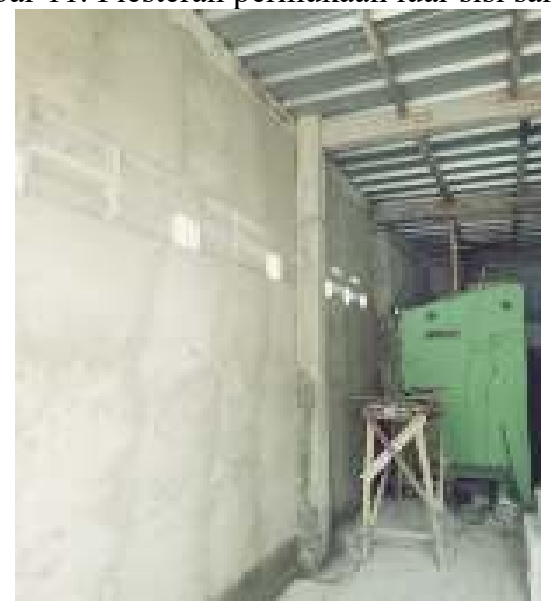

Gambar 12. Plesteran permukaan dalam

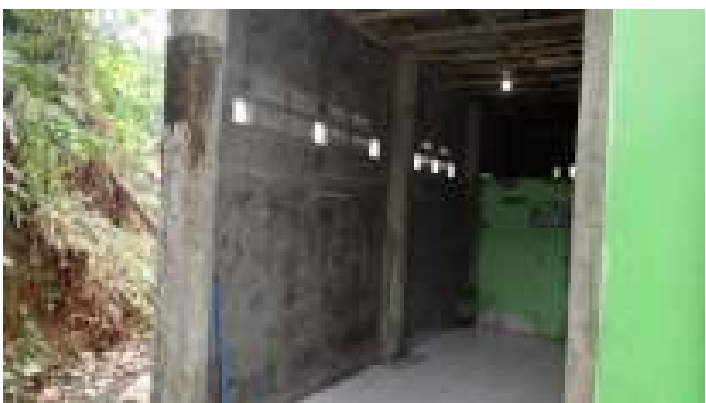

Gambar 13. Plesteran sisi dalam sudah diaci

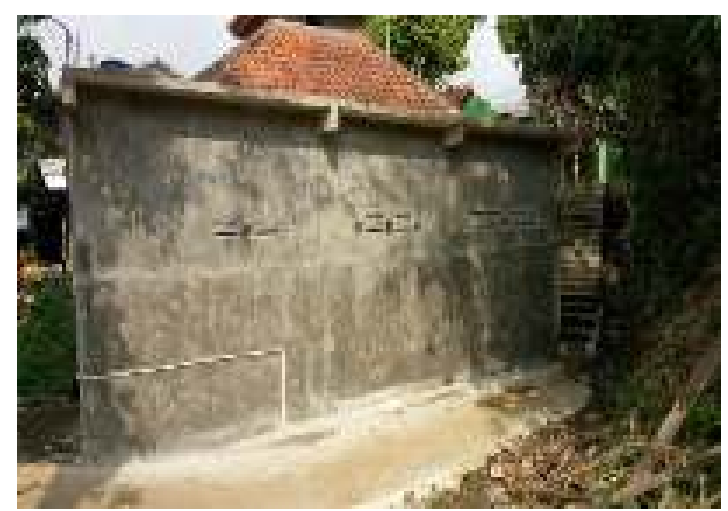

Gambar 14. Plesteran sisi luar sudah diaci 


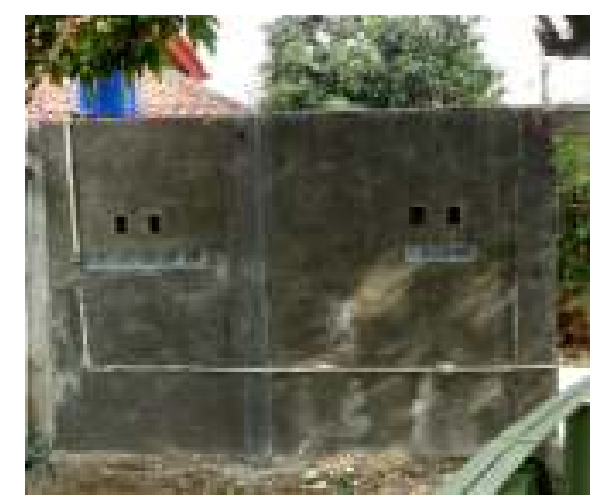

Gambar 15. Plesteran sisi belakang sudah diaci

4. Penggantian Pintu Toilet yang Telah Rusak Ada 2 unit pintu toilet yang akan diganti, pintunya sudah tersedia namun belum terpasang, dengan demikian capaian penggantian 2 unit pintu toilet sampai dengan akhir bulan November 2018 sudah terpasang.

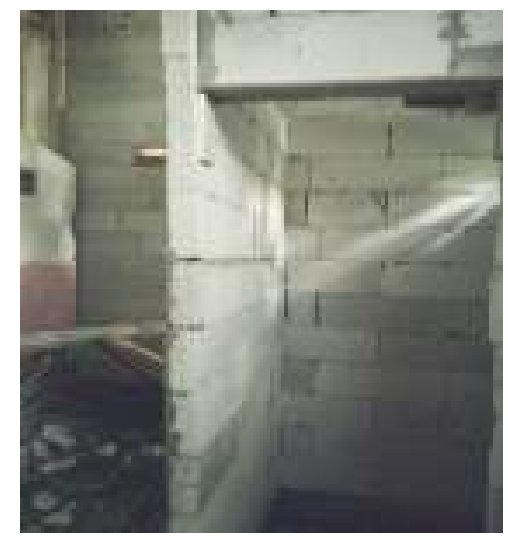

Gambar 16. Pintu toilet belum terpasang

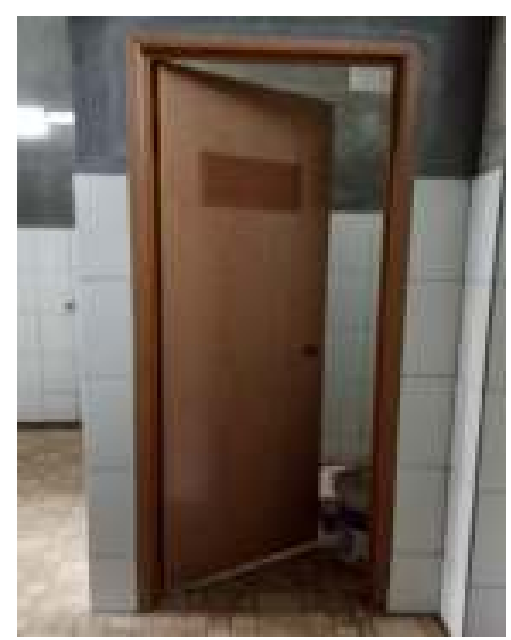

Gambar 17a. Penggantian 2 unit pintu kamar mandi sudah terpasang

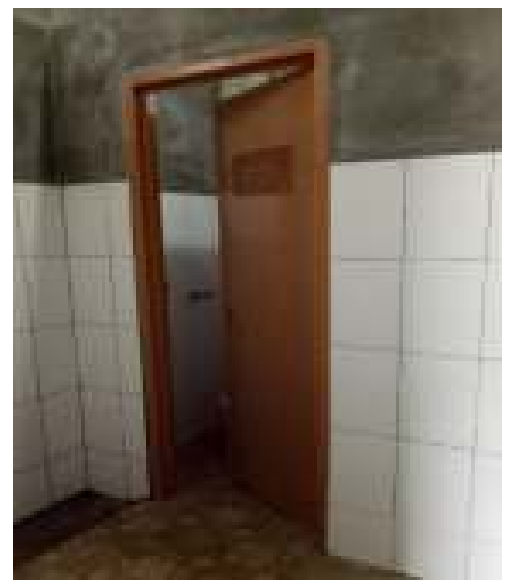

Gambar 17b. Penggantian 2 unit pintu kamar mandi sudah terpasang

5. Pemasangan Keramik Dinding dan Lantai Tempat Wudhu

Keramik dinding dan lantai tempat wudhu belum terpasang, namun bahan keramik sudah tersedia, dengan demikian capaian pemasangan keramik dinding dan lantai sampai dengan akhir bulan November sudah selesai dipasang.

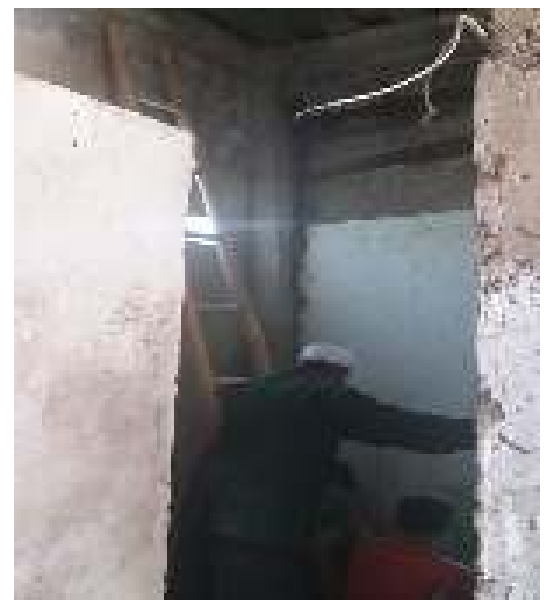

Gambar 18. Keramik lantai belum terpasang

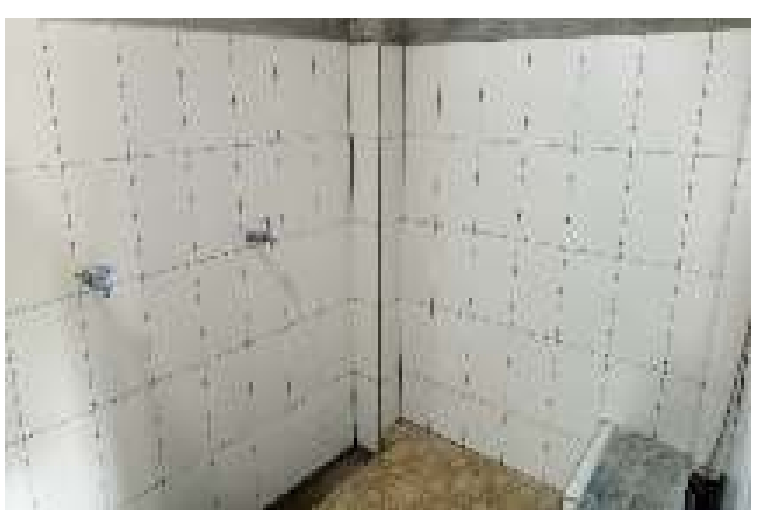

Gambar 19. Keramik dinding tempat wudhu dan toilet sudah terpasang 


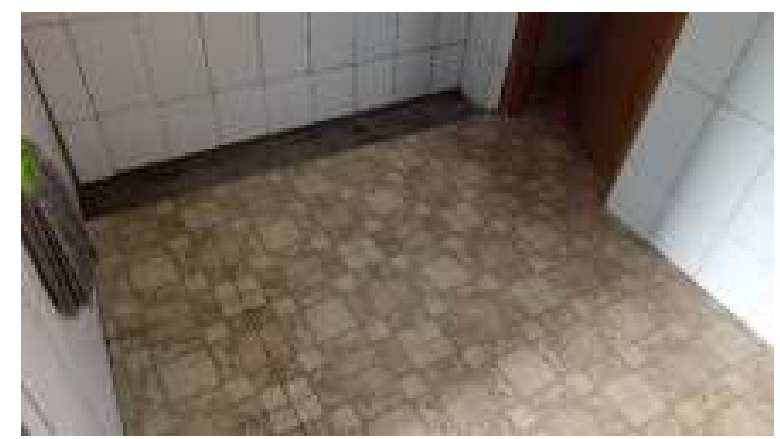

Gambar 20. Keramik lantai tempat wudhu sudah terpasang

Dari beberapa jenis pekerjaan perbaikan Mushola yang di programkan oleh Prodi Konstruksi Gedung sampai dengan akhir bulan November sudah selesai dilaksanakan.

4. KESIMPULAN

\begin{abstract}
Pengabdian Kepada Masyarakat ini menunjukkan bahwa dalam pelaksanaan penyempurnakan kondisi fisik Mushola Al Hidayah Kampung Pondok Manggis, RT.03/RW.04, Desa Bojong Baru, Kecamatan Bojong Gede, Kabupaten Bogor, masih ditemukan beberapa kendala seperti berikut:

1. Struktur dinding toilet yang ada terlalu sederhana tanpa ada dasar pondasinya sehingga ketika dilakukan pemasanagan kolom beton dinding tersebut roboh sehingga harus diganti dengan yang baru yang berarti volume pekerjaan pemasangan dinding dan plesteran bertambah besar.
\end{abstract}

2. Dilakukan penataan ulang tata letak tempat wudhu dan toilet sehingga kedua fasilitas tersebut harus dibongkar.

3. Sebagai leader harus ada tukang batu/beton yang terampil, namun di lingkungan masyarakat setempat tidak ada tenaga tukang yang dimaksud sehingga harus mendatangkan tukang dari tempat lain.

Namun hasil pengabdian menunjukkan bahwa dengan telah disempurnakannya kondisi fisik Mushola Al Hidayah Kampung Pondok Manggis, RT.03/RW.04, Desa Bojong Baru, Kecamatan Bojong Gede, Kabupaten Bogor, prasarana Mushola pun memadai sehingga lebih mengundang banyak warga ke Mushola tersebut untuk meningkatkan ketakwaan serta keimanan kepada Tuhan Yang Maha Esa.

\title{
5. DAFTAR PUSTAKA
}

\section{[1] http://itjen.ristekdikti.go.id}

